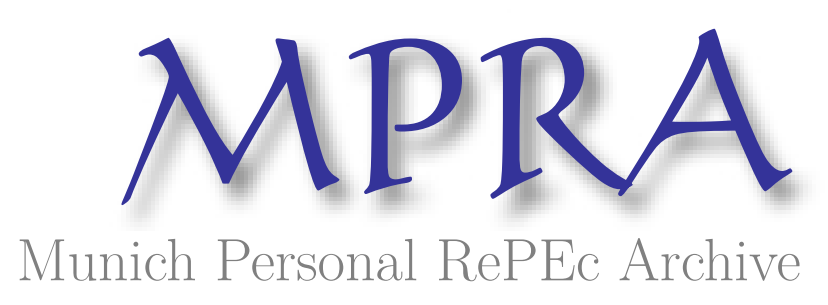

\title{
Theory of Fiscal Federalism: An Analysis
}

Prakash Chandra, Jha

Amity University

2012

Online at https://mpra.ub.uni-muenchen.de/41769/

MPRA Paper No. 41769, posted 15 Oct 2013 03:38 UTC 


\section{Theory of Fiscal Federalism: An Analysis}

Prakash Chandra Jha

Amity University Rajasthan, Jaipur

Abstract: The recent scholarship has made distinction between two generation of literature in fiscal federalism. The study has critically analysed the first generation theory and second generation theory of fiscal federalism. Though the later approaches the problem of fiscal federalism from different perspective, it does not challeng but complements the former. The paper argues that second generation theory is an ongoing effort to bulid a theory in response to fiscal challeneges facing a number of countries. In brief, it is aimed at explaining present-day institutional arrangements which can no longer be adequately explained by employing the first generation theory.

\section{Introduction}

The term 'federalism' in fiscal federalism appears to create confusion to many scholars because it is used to mean both 'federal' and 'unitary' political system. It is assumed in the theory of fiscal federalism that distribution of tax and expenditure powers between different vertical levels of government takes place though informally in country even with system of 'unitary' form of government. The theory also suggests that 'informal' distribution of power supplement the 'formal' provision of federations and may cause 'unitary' states to function like federal system. China is the case in point.

In theoretical terms, fiscal federalism, it is argued, helps understand: (i) the factors determining the optimal degree of fiscal decentralisation; (ii) principles underlining the assignment of functions and sources of finance of governments of different verticle levels; and (iii) to design suitable inter-governmental transfer schemes to fulfill the objectives of 'equity' and 'efficiency' (Rao and Singh, 2005).

Until the early 1990s, fiscal federalism was a largely unexplored area of fiscal policy. But over the last decade, a clear world-wide trend towards fiscal decentralisation has emerged. Decentralisation has brought along with it several associated problems especially in developing countries. This has led to a fresh debate whether decentralisation per se is good for developing countries where sub-national institutions could be weak. Moreover, the developments in the European Union (EU) has contributed to the growing interests in fiscal federalism. 
The first generation theory (FGT) of fiscal federalism is associated with decentralisation of expenditure responsibilities and centralisation of revenue responsibilities for the purpose of achieving 'efficiency' and 'equity' in the federation. It emphasises the importance of transfers for addressing the problems of vertical and horizontal imbalances. It is largely normative and assumes that federal and sub-national decision-makers are 'benevolent' and maximises the social welfare. The second generation theory (SGT), especially the theory of market-preserving federalism assumes that public officials have goals induced by political institutions that often systematically diverge from maximising citizen's welfare. Unlike the FGT which emphasises the importance of transfers for mitigating vertical and horizontal imbalances, the SGT gives more importance to incentives generated by sub-national tax collection for fostering economic prosperity. The SGT has had significant implications for the design of transfer systems so that equalisation goals can be achieved without diminishing the incentives of public officials to foster thriving sub-national economies. In brief, the SGT is in favour of decentralisation of both expenditure and revenue responsibilities; and it gives minimal role to revenue-sharing and inter-governmental transfers. Moreover, it also posits that 'inter-jurisdictional competitions', a 'common market' and 'hard budget constraints', may provide protections against infringements to market operations. The SGT is a emerging theory. Though it approaches the fiscal federalism from different perspective, the SGT does not challeng but complements the FGT.

This article is divided into six sections. The first section identifies in brief the principall reasons for growing interest of scholars in fiscal federalism. The second section delineates FGT of fiscal federalism and various issues associated with it. The third section identifies and analyses difference between first generation theory and practice, especially in developing countries. The fourth section examines the emerging SGT of fiscal federalism, especially market-preserving federalism. The fifth section presents a critical assessment of the theoretical considerations. The sixth section explores some new developments in second generation theory of fiscal federalism. It underlines the fact that a host of relevant issues raised by the theory of market-preserving federalism has led further works towards building SGT. 


\section{Resurgence of Interest in Fiscal Federalism}

Broadly speaking, theory of fiscal federalism lays out a general normative framework for the assignment of expenditure responsibilities as well as revenue responsibilities to different vertical levels of government in a federation and suggests a revenue-sharing mechanism to correct fiscal imbalances. (Rao and Singh, 2005) Principal reasons for growing interest of scholars in fiscal federalism in the recent times are as follows:

(i) Until the decade of 1980s, the issues of fiscal federalism used to receive fairly little attention even in economics; and practically none in the disciplines of political science and public administration. Interest was also confined essentially to the specialists of the subject in the US (Tanzi, 1995: 229). However, as the decade of 1990s advanced, several countries around the world-developed and developing both-began to decentralise their economic powers. The decentralisation trend is often believed to be largely as much a consequence of economic globalisation as it is the result of the domestic regional pressures brought about by the process of economic liberalisation. Consequently, roles and responsibilities of different levels of government not only in federal systems but also in unitary polities have undergone a sea-change.

However, fiscal decentralisation, more importantly in developing countries including India, has led to a host of fiscal problems, many of which the existing literature on fiscal federalism fails to address. Although many industrialised countries have had a long history with decentralised governance, developing countries have recently begun to decentralise. Challenges facing developed countries are often magnified in developing countries, where the institutions necessary for successful decentralisation are weaker (Rodden, Eskeland, and Litvack 2003: 3).

(ii) Besides, the debate and developments within EU with regard to creating a central entity that would transcend the responsibilities of its member-states in some important economic spheres opened up the question of how much power should be transferred to the central entity. Key issues in the debate are who should be responsible for economic redistribution and which functions should be performed exclusively by EU? Thus developments in EU have forced the economists and policy makers to critically look at the existing theoretical literature of fiscal federalism. 
(iii) Another factor explaining the increasing interest in fiscal federalism is the growing dissatisfaction with the role of public sector, especially in developing countries undergoing structural adjustment programmes. Most of the developing countries witnessed explosive growth of their public sector in post-Second World War period. The role of federal governments in income maintenance, income redistribution and stabilisation of economy has expanded. Such developmetal strategies also had found the support of economists on the grounds of efficiency and equity (Keynes, 1964). ${ }^{1}$ With the onset of economic globalisation and liberalisation however, 'neo-institutionalists' or 'neo-liberals' started questioning some of the traditional or first generation theory of fiscal federalism. They stated that greater reliance should be placed on the market and less power should remain in the hands of federal government. By questioning the effectiveness of the federal government's role in stabilising the economy and improving the distribution of income for the purpose of reducing the poverty and unemployment, some neo-liberal economists have reduced the legitimacy of federal government's greater role and have created a presumption in favour of reducing the size of the public sector while giving more powers to both market and sub-national governments. ${ }^{2}$ As part of the public sector reforms, many countries undergoing economic liberalisation are now considering and undertaking devolution of some key functions to subnational-level governments. In terms of resource allocation, various arguments have been advanced to support the view that privatisation and decentralisation would lead to greater efficiency.

(iv) Further, mention must also be made here of international agencies such as World Bank, International Monetary Fund (IMF) and Inter-American Development Bank (IADB) which also encouraged research on fiscal federalism and decentralisation in order to persuade the developing countries to decentralise their public sectors more often to legitimise their own vested interests in market-oriented economic reforms. ${ }^{3}$

(v) Furthermore, perception that the present-day institutional arrangements cannot be explained by traditional theory, which had developed mainly in 50s and 60s, led to growing scholary research to examine the new reality. Notwithstanding the growing interest in research on fiscal federalism, it is observed that whereas there was consensus over the key issues such as which power should be performed by which level of 
government, in the traditional theory of fiscal federalism, there is no consensus in the second generation literature on fiscal federalism. As Oates (1999: 1145) has put:

...most of us working in the field felt more than little uneasy when proffering advice on many of the decisions that must be made on vertical fiscal and political structure. We have much to learn!

This is also perhaps the reason that interests in the subject has begun drawing more and more attention both at academic and policy-planning levels in almost all countries, as they have come to confront with new fiscal problems; and fiscal federalism has today thus emerged as an important subject of study.

Theory of fiscal federalism have recently been divided into the first-generation theory and the second-generation theory. Separate examination of each of them is in order.

\section{First Generation Theory (FGT)}

Cassical normative theory of fiscal federalism is also known as first generation theory (FGT). The FGT "was solidly embedded in the view of public finance that prevailed in the 1950's and 1960's" (Oates, 2005). It offers some general prescriptions on the allocation of functions among vertical levels of government and the assignment of fiscal instruments. Generally understood, the function of public sector is to ensure an efficient use of resources to establish an equitable distribution of income and to maintain the economy at high level of employment with reasonable price stability. In other words, the functions of public sector can be divided into three branches: allocation of resources i.e. provision of public goods and services; redistribution of income; and macro-economic stabilisation of economy (Musgrave, 1959; Musgrave and Musgrave, 1984). ${ }^{4}$ The FGT recognises the fact that both decentralised and centralised forms of government have advantages and disadvantages in performing these tasks (Oates, 1972). The FGT thus by seeking to combine the advantages of both the centralised and decentralised form of government provides the guidelines as to which functions should be placed at the level of federal government and which should be placed at the decentralised levels of government. Theory contends that the federal government should have basic responsibilities for the macroeconomic stabilisation of economy and income redistribution. This is because federal 
government always possesses a far greater capability to maintain high levels of employment with stable prices than a sub-national government. Similarly, the scope of redistributive programme is limited by the potential mobility of residents which tends to be greater, the smaller is the jurisdiction. This suggests that since mobility across national boundaries is generally much less than within a nation, policy of income redistribution has much greater success if carried out at the national level ( Ibid).

The FGT favours the decentralisation of allocative functions. The so-called 'decentralisation theorem'--advanced by Wallace E. Oates--states that "each public service should be provided by the jurisdiction having control over the minimum geographical area that would internalize benefits and costs of such provision" (Tiebout, 1956: 416; Oates, 1972). ${ }^{5}$ One of the main proponents of the FGT, Oates provides strong rationale for decentralisation of public goods and services on following grounds:

(i) The provision of public goods and services by federal government leads to uniform level of consumption and utilisation of goods and services respectively across all regions. Such uniformity may lead to inefficiencies. Decentralised provision allows governments to cater better to the tastes and needs of local residents.

(ii) The possibilities of welfare gains in case of decentralised provision of goods and services are further enhanced by the phenomenon of consumer mobility. "Citizens vote with their feet". This implies that a consumer can to some extent select his place of residence that provides a fiscal package best suited to his or her preferences.

(iii) Decentralisation may also result in greater experimentation and innovation in production of public goods and services. With a large number of independent producers of public good, one may expect a variety of approaches that, in the long run, promise greater progress in the modes of production of such goods and services.

(iv) Inter-jurisdictional competition as a result of decentralisation may also lead to efficiency in the provision of public goods and services. This means that if one jurisdiction, for example, discovers a particular effective way of providing certain service, the governments of other jurisdictions are also likely to adopt similar techniques, or even better techniques and methods.

(v) Finally, it is argued that the decentralisation of allocative functions may lead to more efficient levels of public output because expenditure decisions are tied more closely 
to real resource cost. If a community is required to finance its own public programme through local taxation, its members are more likely to weigh the benefits of the programme against it actual cost (Oates, 1972).

Thus, in brief, normative theortical considerations strongly support decentralisation on the ground of efficiency, accountability, manageability, and autonomy principles. However, this does not mean that FGT favours a decentralised model for assignment of tax. It is important to note/emphasise here that while the case of decentralisation of expenditure responsibilities is widely accepted, the FGT is very cautious about the decentralisation of revenue responsibilities. Broadly, there are some very major theoritical arguments put forth as justification for assignment of expenditure and revenue responsibilities; and the next two sub-sections will describe them in some details.

\section{(a) The Assignment of Expenditure and Revenue Responsibilities}

Allocation of expenditure and revenue responsibilities to different levels of governments is the most fundamental issue in a federation. The conventional wisdom is that expenditure assignment must precede tax assignment; but not necessarily as a rule. It is so since tax assignment is, in general, guided by the expenditure assignment at different levels; and this can not be worked out in advance of expenditure assignment.

As has been discussed in the preceding pages, at the theoretical level, it is argued that the federal government should be given exclusive authority in carrying out services which relate to stabilisation of economy and redistribution of income. National goods whose benefits are national in scope should be provided by the federal government. Similarly, the federal government should take the responsibilities for certain services which require service area larger than a local jurisdiction for cost-effective provision. These include, for example, transportation services, water and sewage, etc. Besides, the federal government should also be given a role in providing compensatory grants for spill-out of benefits from state level provision of services. A similar role for each state is in order for spill-out of benefits from local provision of services within their jurisdictions. All other services could and should best be provided by the local governments with federal and state/provincial governments having some role in defining minimum standard. Table1.1 shows the broad theoretical guidelines in expenditure assignment. 
The FGT, however, favours centralisation of revenue responsibilities. The reason is that lower level government would otherwise engage themselves in 'beggar-thy-neighbour' competition when tax is levied on mobile factors such as capital and labour. Such interjurisdictional competition would turn out to be self-defeating and result in reduction in taxation and in turn would lead to under-provision of public goods and services. Morever, a decentralised tax system would hinder the functions of internal common market, that is, free mobility of resources. Therefore, as opposed to expenditure responsibilities, a centralised tax system is often preferred. Benefit taxes such as user-charges and property tax are advocated to be assigned to the sub-national level governments. Richard Musgrave, on the basis of 'equity' and 'efficiency' criteria, enumerates which taxes should be assigned to federal government and which should be placed at the sub-national levels of government. Followings are the broad guidelines suggested by Musgrave and Musgrave (1984):

(i) Taxes suitable for economic stabilisation should be assigned to the federal government;

(ii) Progressive redistributive tax should be centralised;

(iii) Taxes on mobile factors of production are best administered at the central level;

(iv) Tax base highly unequally distributed between different jurisdictions should be centralised;

(v) Taxes on immobile factors of production are best suited for local levels;

(vi) Residence-based taxes such as sales of consumption goods to consumers or excise are suitable for states;

(vii) Benefit taxes and user charges might appropriately be used at all levels of government. Table 1.2 further elaborates the above guidelines and theoretical insights.

The preceding sections has briefly examined the normative principles of assignments of expenditure and tax responsibilities in a federal system. The practice, however, exhibits quite different properties from principles. For instance, in Canada, most major tax bases such as income tax are co-occupied by the federal government. Function of income redistribution is shared between different levels of governments which is in contrast to the FGT, as discussed so far. 
From the preceding discussions, it is apparent that due to efficiency and equity considerations, there is no reason to expect that the distribution of financial resources among governments will correspond to the distribution of expenditure responsibilities. Thus the federal government has more taxing powers, but comparatively less expenditure responsibilities; and, on the other hand, sub-national governments generally have less taxing authorities but more expenditure functions to perform. This, in consequence, contributes to what is known in the SGT as 'vertical fiscal imbalance'(VFI) (Shah, 1991).

Unlike VFI, 'horizontal fiscal imbalance'(HFI) refers to inconsistency between revenue raising and fiscal needs of government at the same level. The different units of government within a particular level cannot be expected to have equal fiscal capacity ( involving both equality of revenue-raising capacity and equality in costs of providing comparable services) except by chance, HFI in a federal system implies the existence of some form of revenue-sharing arrangements or equalisation grants to remove the inequities. The next sub-section examines this aspect further.

\section{(b) Inter-governmental Transfers and Revenue-Sharing}

A critical component of fiscal federalism is inter-governmental transfers and revenuesharing. Both the inter-governmental transfers and the revenue-sharing arrangement are employed to fulfill a variety of objectives. Invariably therefore, the design of a given transfer scheme depends on the purpose for which it is given. The SGT has underlined several economic rationales for inter-governmental transfers (Ahmad and Craig, 1997):

(i) VFI is generated invariably by the expenditure and revenue assignment among different levels of government in a federation. In most countries, the federal government retains the major tax bases, leaving insufficient fiscal resources to the sub-national governments for covering their expenditure needs. Inter-governmental transfer is, therefore, needed to balance the budget at the sub-national level. However, individual policy choices also play a significant role in determining the resulting ex-post-vertical fiscal imbalance. If lower level of government chooses to increase spending or not to raise assigned taxes, the VFI would increase. Thus if transfers were designed solely to close the VFI, there would be little incentive for lower levels of government to raise own revenues or restrict or manage expenditures efficiently. Unless there are objective criteria for the 
determination of transfers, 'gap-filling' to finance sub-national deficits is likely to lead to macro-economic difficulties as well as indeterminate 'bargaining' between the federal and sub-national levels of government. Since VFI tends to favour the federal government, the size of transfers to sub-national levels of government often may be function of macroeconomic stabilisation concerns.

(ii) HFI arises because of the fact that some sub-national governments may have better access to natural resources or to other tax bases that are not available to others; they may also have higher income levels than those in other jurisdictions. These are commonly referred to as differences in fiscal capacities.

(iii) Some sub-national governments may have extraordinary expenditure needs because they may have high proportions of poor, old, and young population. The net fiscal benefit (NFB), measured by the gap between fiscal capacity and fiscal need, is often caused by such uncontrollable factors and therefore should be addressed by federal government transfers.

(iv) Inter-governmental transfers are used to address inter-jurisdictional spill-over effects. Some public services have spill-over effects (or externalities) on other jurisdictions. Measures such as pollution control, inter-regional high-ways, higher education (highly-educated people may leave for other jurisdictions), fire departments (may be used by neighbour jurisdictions), etc. Without reaping all the benefits of these projects, a local government may tend to under-invest in such projects. Therefore, it is essential for the central government to provide incentives or financial resources to address such problems of under-provision of certain services.

Scholars of public finance and fiscal federalism broadly group the intergovernmental transfers into the following two categories: conditional transfers (or specific purpose transfers); and unconditional transfers (or general purpose transfers).

(i) Conditional transfers may consist of matching transfers; non-matching transfers for specific purposes; and block transfers. In case of conditional transfers, the federal government specifies the purposes for which the recipient sub-national government can use the funds. Such transfers are often used to address concerns that are highly important to the federal government such as projects with inter-regional spill-over effects but which might be considered less so by the sub-national governments. As stated earlier, conditional 
transfers can be of several types -- matching transfers, non-matching transfers for specific purposes, and block transfers. Further, each of these may be without a redistribution criteria or may be either open-ended or closed-ended. In the case of matching open-ended transfers, a federal government contributes the same amount to be spent by the subnational governments in an area. In an open-ended matching transfers, the transfers of federal government depend upon the recipient's behaviour. If sub-national government's expenditure is vigorously stimulated by the programme, then the federal government's contributions may be quite large and vice versa.

Contrary to the above, in matching closed-ended transfers, the federal government specifes some maximum amount that it will contribute in order to put a ceiling on the cost borne by it. Such transfers are used in most countries because of concern of budget control. Different countries employ different mechanisms. In non-matching block transfers, federal government contributes a fixed sum of money with stipulation that grant be spent on specified public goods or services. In this case, the recipient government is not required to match the contribution of federal government.

(ii) Unconditional transfers, as the name suggests, is characterised by the absence of restrictions over its use by the recipient governments. The main justification for this grant is to equalise fiscal capacities of different sub-national governments in order to ensure the provision of minimum or reasonable level of public services.

\section{Difference between Theory and Practice}

In the FGT, as discussed in the preceding pages, the federal government is assumed as 'benevolent'(Brennan and Buchannan, 1980: 185). ${ }^{6}$ It also presumes the principal-agent type of relations between the federal and sub-national governments in which the former can design its own policy without any consultation with the later. The practice may, however, provide a picture quite different from that envisioned at the abstract theoretical level. It has been noted that inter-governmental fiscal relations are subject to political bargaining and compromise by different governments and political forces in federations. One can say that inter-governmental transfers cannot be independent of sub-national interests. Furthermore, transfers are often made for vested political gains; for instance in 
order to stay in power and other purposes. Besides, the formula used to allocate the equalisation transfers also differs from country to country.

Bird and Smart (2002) highlight the political use of inter-governmental transfers. They argue that it may be necessary, for example, to transfer some resources to jurisdictions that do not really need them. It may also be essential to transfer resources simply in order to keep some economically non-viable sub-national governments alive in power for purely political reasons. From an economic point of view the problem is to avoid inflicting collateral damage in course of achieving whatever be such political objectives. Bird and Smart (2002) state that when major changes are made in inter-governmental fiscal arrangements, they often result from important political developments that create the need and opportunity for change but not the time to think through changes adequately. Moreover, once a political settlement is reached in inter-governmental arrangements, it often proves exceptionally hard to alter thereafter. Bird and Smart (2002: 899) contend:

Since circumstances and objectives differ from one country to another country, no simple uniform pattern of transfers is universally appropriate but experience around the world makes it clear that if services are to be efficiently provided, transfers must be designed so that those receiving them have a clear mandate, adequate resources, sufficient flexibility to make decisions and are accountable for result.

Barrowings by decentralised sub-national governments in developing countries often cause political controversies; and have led to debates and discussions at the academic and policymaking levels over the negative implications of borrowings, particularly in federal countries. It is often argued that federal system is more vulnerable to such problems. FGT had failed to recognise the problem; for it failed to see that the sub-national governments also influence macro-economic management though not so overtly. The problems of borrowing and incurring debts by sub-national governments and thereby contributing to the problem of macro-economic management, especially in decentralised sytem in developing countries, is admittedly as much an economic problem as it is a political problem. This calls for the study of political institutions--an aspect which has been neglected in the FGT since it has been confined essentially to the study of economic issues under fiscal federalism. It is only now that some interest among economists to study political aspects of 
fiscal federalism is discerned; inasmuch, some political scientists have also entered into the territory of fiscal federalism. Before proceeding further with the analysis, it is worthwhile to examine whether sub-national borrowing is per se good or bad; for theory of fiscal federalism tends to dabble on this issue with vigour and interest.

Bird (2004) observes that "borrowing may of course be the economically appropriate way to finance capital outlays". He further argues that in order to achieve both allocative efficiency and inter-generational equity, it is often good to finance long-lived investment projects by borrowing rather than relying solely upon either current public savings or transfers from federal government. Since sub-national borrowings can be good as well as bad, it is as important therefore to encourage the good borrowing and discourage bad borrowing. But how to discourage bad borrowing by sub-national governments in federal developing countries is one of most troubling problems in the area of fiscal federalism. Bird afirms that imposing too strict and arbitrary limits by federal government to subnational borrowings may have perverse results. This is because debt limits and similar controls raise 'moral hazard problems' precisely because they prevent 'market discipline' from being applied (Bird, 2004). ${ }^{7}$ In the OECD federations, bond markets at sub-national levels function properly. Sub-national governments have budgetary laws and voters punish fiscally irresponsible sub-national governments (Joumard and Kongsrud, 2003: 64). This situation contrasts with emerging markets (especially federal states) where the absence of one or more of these constraining factors encourages differences between the political incentives facing federal and sub-national officials. Under such conditions, federalism in fact enhances the possibility that sub-national authorities will have few incentives to bear the costs of adjustment policies implemented by federal officials. The lack of incentives for reform is significant, as sub-national governments in many federal developing countries spend more than half of total public sector expenditure, making the success of adjustment policies conditional on their implementation by sub-national governments. Ironically, the FGT has ignored the political incentives available to sub-national politicians in decentralised contexts and thus have provided an incomplete account of decentralisation. The role of sub-national political leadership is thus particularly significant with respect to macro-economic stability and reform since sub-national officials often have few incentives to manage decentralised spending in a macro-economically responsible manner (Wibbels, 
2000). Unlike federal government, sub-national governments face few of international incentives for economic reform and electoral considerations discourage sound sub-national policy, particularly where decentralised politics is dependent on patronage. As a result, the fiscal incentives of sub-national governments often run in the directions of over-spending. This places a premium on the policy of macro-economic stability pursued by federal government. Hence careful attention needs to be paid to sub-national borrowings to avoid serious fiscal problems. This can be done either by redesigning inter-governmental fiscal relations to reduce the temptation on the part of sub-national governments to borrow irresponsibly or by enacting legilation for constraining such borrowings (Wibbels, 2000).

To sum up, how to avoid 'soft-budget constraints' and impose 'hard-budget constraints' at the sub-national levels, especially in federal developing countries, is an uphill task. There are numerous instances, where excessive barrowings by sub-national governments have led to fiscal crisis. Since 'hard-budget constraints' through market forces would take longer time in liberalising economies, this calls for strict legally binding rules at least for some years until market forces acquire the maturity to impose 'hard budget constraints' ${ }^{8}$ The FGT, as has been discussed earlier, fails to capture these problems; some of the new theoretical writings aiming at building a second-generation theory, however, deals with these issues.

\section{Second Generation Theory (SGT)}

Since last deceade, there have been efforts by various scholars-- both politcal scientists and economists -- to produce a second-generation theory (SGT) of fiscal federalism. Unlike the FGT, the SGT is emerging theory. As Oates (2005) has noted:

The key difference, or contribution, of the SGT comes from its focus on the political economy of intergovernmental structure-on the incentives embodied in various political and fiscal institutions.

The theory of market-preserving federalism is, argueably, one of the most influential theory towards building a SGT. The theory of market-preserving federalism has been criticised by a number of scholars but it has raised a host of important fiscal issues facing liberalising economies. It seeks to complement the FGT rather than challenge it. Before 
examining the theory of market-preserving federalism, a brief discussion about public choice theory merits some attention.

Unlike the FGT discussed above, public choice theory takes a radically different view about government. It regards politicians as 'rent-seeking individuals' using their positions to pursue private goals, and government as institutions that encroach upon individual freedom and seek to increase their hold on the private economy as much as possible. Public choice theorists view government as 'leviathan' and emphasise the importance of institutional rules and arrangements forcing politicians to serve the public interest in the pursuit of their own goals and limiting their discretionary power (Buchanan, 1995: 19-27). Inman and Rubinfeld (1997) have articulated a complex positive theory about how the politics of public expenditure programmes and budgeting introduces a range of inefficiencies. These economists and several others approach the problems of fiscal federalism with the assumption of a 'malevolent government'.

Scholars of the 'market-preserving federalism' build upon the works of public choice theorists such as Geoffrey Brennan and James Buchanan, and others, but they do not consider government as 'malevolent' nor like the FGT they assume the government to be inherently 'benevolent'(Qian and Weingast, 1997: 83-84). Their theory is influenced by advances in the 'theory of the firm' which studies a wide range of incentive problems that plague firms, working under the assumption that no reason compels managers to favour share-holders (Ibid) ${ }^{9}$. The 'new theory of firm' shows 'how institutional and governance structures can be structured so that, in interacting with the market, they align incentives of managers with the interests of shareholders". Just as in the new theory of firm, scholars of the litrature of market-preserving federalism also assume that "there is no natural reason for political officials to further the interests of citizens". Scholars of market-preserving federalism take more realistic positions and argue that, if given opportunity, government officials will work for maximizing their own interests rather than serving the interest of the citizens. Again by drawing parallel with the 'new theory of firm', they argue that "the appropriate political institutions align incentives of political officials and citizen welfare" (Qian and Weingast, 1997: 84). As against the FGT--associated with Musgrave, Tiebout and Oates which has been discussed earlier and which is based on 'efficiency' and 'equity' criteria--and like public choice theory, theory of 'market-preserving federalism' interprets 
federalism primarily as a way of imposing discipline on self-serving politicians and governments; and attacks the abuse of power and excessive growth of public sector. The new theory underlines the fact that growth of public sector, due to centralisation of tax responsibilities, have prevented multilevel governments to compete with each other vertically as well as horizontally. Lack of competition has in turn led to inefficiency. Proponents of the new theory, therefore, maintain that the allocation of tax and expenditure responsibilities among different levels of government in a country should be so done that it leads to a maximum degree of competition among governments. Competition thus arguably would lead to efficiency. The new theory appears to favour 'efficiency' considerations over 'equity'. It underlines that competition among sub-national governments forces governments to represent citizen interests and preserve markets. It is to be noted that Tiebout, as early as in 1950s, had underlined the importance of 'interjurisdictional competition' for efficient provision of goods and services (Tiebout, 1956). Theory of market-preserving federalism further suggests that, beside efficiency, interjurisdictional competition serves as a disciplinary device to punish inappropriate market intervention by lower government officials (Qian and Weingast, 1997: 85). By studying economic development in China, it suggests how jurisdictional competition within federalism leads to the endogenous emergence of 'hard-budget constraints'. Further, competition among different jurisdictions can also reduce regional inequality without centrally-mandated redistribution. Emphasis thus in the new theory is on the natural process of equalisation through competition. It sees political decentralisation in terms of its fiscal capacity to sustain a productive and growing market economy. (Jin, Qian and Weingast, 2005). Its main proponent, Weingast (1995, 1) observes:

A fundamental political dilemma of an economic system is this: A government strong enough to protect the property of right and enforce contracts is also strong enough to confiscate the wealth of its citizens. Thriving markets require not only the appropriate system of property rights and a law of contracts, but a secure political foundation that limits the ability of the state to confiscate wealth.

The main attraction of federalism for Weingast is its potential for providing a political system that can limit the ability of the federal government to confiscate wealth of sub- 
national governments while supporting an efficient system of markets. Accordingly, Weingast argued that the theory of market-preserving federalism solves this dilemma by combining strong sub-national governments with a federal government enforcing nationwide free markets and free mobility of factors, goods and services. Weingast classifies a federal system as market-preserving if the primary responsibility for regulatory and economic development policies remains with the sub-national governments, common market is enforced; and sub-national governments have no access to money creation or to central government's bail-outs for bad local projects or excessive debts. ${ }^{10}$ The marketpreserving federalism, according to Weingast (1995), should meet the following set of five conditions:

(i) A hierarchy of governments with a delineated scope of authority (for example, between the national and sub-national governments) exists so that each government is autonomous within its own sphere of authority.

(ii) The sub-national governments have primary authority over the economy within their jurisdictions.

(iii) The national government has the authority to police the common market and to ensure the mobility of goods and factors across sub-governmental jurisdictions.

(iv) Revenue-sharing among governments is limited and borrowing by governments is constrained so that all governments face 'hard-budget constraints'.

(v) The allocation of authority and responsibility has an institutionalised degree of durability so that it cannot be altered by the federal government either unilaterally or under the pressures from sub-national governments.

In brief, unlike the FGT, theory of market-preserving federalism is concerned about the ill-effects of the growth of public sector as a consequence of centralisation of responsibilities. 'Competition' is the main crux of the new approach. It favours 'common market' which implies that the there is no restriction over the mobility of goods across a country. It demands the following assignment rules: local governments should be responsible for all policies of economic regulation and development; while the federal government is responsible for developing a federal constitution committed to the principles of free and open markets, and for monitoring and enforcing its proper implementation. Theory emphasises on the importance of federal government imposing 'hard-budget 
constraints' on sub-national governments. It, however, clearly warns that formal constraints imposed by strong federal government are problematic. Weingast writes that the answer to inter-governmental commitment problems "cannot be simply a written rule, for rules can be changed, avoided, or ignored"; and that "a sustainable system of federalism...must prevent the central government's ability to overawe the lower governments" (Weingast, 1995). It can be added here that the litrature of market-prserving federalism is an attempt on the part of some scholars to provide a second generation theory. The theory has attracted lots of criticims in the recent times. But at the same time, some of issues and problems raised by it has led to further works by scholars leading to renewal of interests in the study of fiscal federalism. Before this is discussed, the next section makes a critical assessment of the theory.

\section{Critical Assessment}

Critics attack the FGT for taking 'Benthamite view', which assumes that federal government is 'benevolent' and would do everything to counter market failure. The federal government and its agents are supposed to work toward enhancing the welfare of the people. Inman and Rubinfeld (1997) thus maintain:

It fails to explain why politicians and bureaucrats in fact in the manner they actually do or why there are serious instances of elite capture of public services provided, even in formal democratic societies characterized by oligarchic power structures. Consequently, the analysis does not provide much guidance on how the institutions and incentives can be structured to achieve the economic and political goals of federalism. When, in fact, the institutions create a structure of incentives which leads to redistribution in favour of social interest groups, the very concept of decentralization and its ability to enhance efficiency in service delivery is questioned.

Both public choice theorists and exponents of the theory of market-preserving federalism fail to recognise the role of political institutions and to a limited degree the political federalism. In the recent times, however, some scholars have attempted to extend the conceptual framework to include additional institutional dimension of multi-level 
governments. They have extended traditional economic analysis to explicitly consider political goals in the government objective functions and examine trade-offs between political and economic objectives (Ibid).

As has been stated, Weingast and his collaborators lays three main pre-conditions for federal system which, in their view, would make a 'market-preserving federalism'. These conditions are: decentralised government has primary regulatory responsibility over economy; the system constitutes a common market in which there are no barriers to trade; and decentralised governments face 'hard-budget constraints'. Thus what follows from this is that lower levels of government have neither the capacity nor access to unlimited credit. Secondly federal government should not be ready to bail sub-national governments out in instances of fiscal distress. 'Hard-budget constraint' implies that decentralised governments must place their basic reliance on self-financing, or own sources of revenue. They must not be excessively dependent on transfers from higher levels of government. Theortically speaking, the idea appears to be good. But as the experience of developing countries suggests, this is unlikely to be a realistic premise for them. Because in developing countries, sub-national governments are invariably heavily dependent on federal transfers and have limited access to own source of tax and other revenues, thereby resulting in greater 'vertical fiscal imbalance'. It can be argued that to the extent that subnational governments manage their expenditure functions efficiently while depending, for much of their resources on transfers from a higher level of government, there is no problem. At the same time, it can also be argued that uni-directional dependence, as the expericnece of several countries including India suggests, could reduce the incentives for responsible fiscal decision-making by sub-national level of government.

While the theory puts excessive emphasis on the importance of federal government imposing 'hard-budget constraints' on sub-national governments, it does not elaborate how that can be done without formal rules. The theory of 'market-preserving federalism' rather clearly warns that 'formal constraints' imposed by strong federal government are problematic. It fails to explain how 'hard-budget constraints' at sub-national level would take place, especially in developing countries, where market (unlike as in the case of US and Canada) does not impose such constraints. Moreover, 'hard or soft budget constraints' are inherently a political problem. What goes on in fiscal federalism often is a result of 
political federalism. Thus any institutional reform for the purpose of establishing 'hardbudget constraints' is not possible for a federal government in a unilateral manner in federation. This requires the agreement of sub-national governments which is often difficult to come. The theory of 'market-preserving federalism' fails to examine this aspect.

Both the FGT and the theory of 'market-preserving federalism' often fail to distinguish between fiscal federalism in federal system and fiscal federalism in unitary system. The failure to distinguish federal system from unitary system, perhaps for the temptation of a broader approach, the new theory too like the FGT considers most of the problems of the two different systems as same and thus provides similar solutions. It is true that government in federal system has the same general responsibilities in relation to fiscal policy as government in countries with unitary system: the maintenance of stability in prices, income, employment and the balance of payments and the encouragement of balanced economic growth; the promotion of an equitable distribution of personal incomes and wealth; and provision of public goods and services to improve living standards of people and achieve an efficient allocation of resources. But whereas, unitary government carries out these responsibilities independently of other governments (subject to such constraints as may be imposed by the country's external relationships and subject also to any delegation of responsibilities to sub-national governments); in a federal system the responsibilities are assigned between two levels of autonomous governments, for the purpose. In a federal system, constituent units have constitutionally guaranteed legislative powers. According to Breton, what distinguishes federalism from decentralised unitary system is "the ownership of property right". Thus what distinguishes federal system to a unitary system is that whereas in the former power assigned to different levels of government can not be extinguished unless the constitution is ignored or amended, in the later, delegated power at lower levels of government is at the discretion of federal government and can be taken away at any time (Breton, 2000: 15-16). ${ }^{11}$

The the theory of 'market-preserving federalism' too like the FGT has tried to explain the problems of fiscal federalism in isolation from political federalism. More specifically it has failed to account for difference in the political incentives facing subnational leaders in federal and unitary systems. Both the first and second generation 
theories of fiscal federalism therefore have argued that the issues faced by unitary and federal countries are largely the same. The difficulty with this perspective is that it fails to account for the crucial role of political accountability. The new theory like the FGT has not differentiated between decentralisation in nations where sub-national official have little power to define budgetary priorities (unitary system) and nations where these officials have substantial freedom from federal government in fiscal policy (federal system). A unitary system may be highly decentralised in terms of spending without creating any pressure on macro-economic performance because sub-national governments have little genuine authority to federal government's policy. In contrast, the importance of subnational incentives is accentuated by significant fiscal decentralisation in federal systems. Moreover, it is generally observed that sub-national politicians in federal systems have greater borrowing privileges, fiscal responsibilities and political autonomy than their counterparts in unitary systems where local and state/provincial governments are primarily sub-ordinates to the federal government. Federal contracts/negotiations/agreements that result in centralisation or decentralisation themselves result from highly politicised processes and such bargains may result in poorly designed federal arrangements. Unplanned decentralisation in turn could generate a variety of undesirable outcomes-- from severe macro-economic imbalances and low growth to poor delivery of services, corruptions, fiscal crisis and inequity across jurisdictions.

However, as several emperical studies have failed to show the relationship between fiscal decentralisation and economic performance, hence the argument of scholar of 'market-preserving federalism' that fiscal decentralisation leads to better economic performance, does not appear to be very convincing (Oates, 1999). This theory also sees only the beneficial side of sub-national fiscal competition as a disciplining factor for restraining sub-national government from over-spending. But negative aspects of competition have been neglected. There are quite a number of scholarly studies which point out that sub-national fiscal competitions, especially in developing countries, have led to negative results. Thus, the potential for fiscal decentralisation for improving economic and political performance must be evaluated in terms of the specific circumstances of the individual country. It is to be emphasised here that weakness/absence of inter- 
governmental institutions often leads to bad competition among sub-national governments. The theory fails to recognise this point.

No wonder therefore, the theory of 'market-preserving federalism' has been criticised by a number of scholars. Rodden and Ackerman have criticised this approach for its failure to characterise fully the nature of the political structures that would comprise a marketpreserving federalism. They state:

With its lack of political foundations, market-preserving federalism leaves too important questions unanswered to be useful as a prescriptive model for institutional reform in the developing world (Rodden and Ackerman, 1997: 1571).

Rubinfeld finds the theory "insufficiently specified to serve as base for reliable policy analysis". But he, however, maintains that the model "can be improved rather than rejected" (Rubinfeld, 1997: 1581). Wibbel finds the imposition of "hard budget constraints by strong centre...misplaced in market-preserving federalism litertaure". 'Hard-budget constraint" "is not consistent with the market preserving literature which recognizes that a strong centre is likely inconsistent with the market" (Wibbels, 2004: 477).

Despite being bitter critics of the theory of market-preserving federalism, Rodden and Ackerman (1997:1571) have underlined the importance of theory in the following manner:

It does, however, raise a number of important positive questions that deserve further research. The theory of market-preserving federalism moves institutional economics and developmental studies in a new direction rich with potential. By examining the credibility of commitment made by political leaders in competitive multigovernment system, Weingast and his collaborators open up a fruitful line of inquiry.

To sum up, notwithstanding the fact that theory of market-preserving federalism has been criticised from policy makers, economists and political scientists, it has, however, raised several issues such as the establishment of 'hard-budget constraints'; common market; decentralisation of taxation; among others, which appear to be quite promising. It recognises the fact that strong fiscal incentives for lower level of government leads to healthier economic development. A number of issues raised by it have led to further studies by scholars on fiscal federalism towards building a SGT. There is growing 
realisation among second generation scholars that the FGT cannot explain present-day institutional arrangements. This has/is given/giving rise to new literature. Having crtically examined the market-preserving federalism, it is desirable to see what insights some new liturature of fiscal federalism provides.

\section{New Developments in Second GenerationTheory (SGT)}

As noted in the last section, theory of market-preserving federalism by Weingast and his collaboraters has been subjected to strenuous criticisms. Nevertheless, the theory has generated unprecedented interests among scholars to examine many of issues either left unanalysed or not adequately analysed. The second-generation literature on fiscal federalism today is wide ranging in terms of its sources. Ulike the FGT which was mainly confined to the contributions made by the scholars of public finance, both economists (not only specialists of public finance but also specialists of other sub-fields of economics) and political scientists have/are contributed/contributing to the SGT. Diversity of literature makes it difficult to characterise the SGT in a simple and systematic way. As Oates $(2005,70)$ has pointed out:

I find it much more difficult to characterize the second-generation theory. This is, in large measure, because it is an emerging perspective that it is quite wide ranging in the issues that it addresses and the analytical methods it employs.

The SGT discusses such issues as whether decentralisation is good or bad and what makes it so? What kind of political and economic institutions are needed to help decentralisation yield positive result? Decentralisation also brings to fore the issue of soft and hard budget constrainsts. The issue of 'soft-budget constraints' and the 'perverse incentives' they create at sub-national levels is, arguabley, a major theme in much of the recent literature in fiscal federalism. The existence of 'soft-budget constrainsts' brings to fore the federal government's policy of 'bail-outs'. This also represents, one of the principal dangers in a decentralised fiscal system. A weak federal government can also result in fiscal problems. This does not however mean that new literature oppose decentralisation but it underlines that it should be supportated by important institutions. What should be the optimal 
decentralisation and what institutions is required to support it is again depends on specific countries ( Rodden, Eskeland and Litvack 2003; Weingast 2005).

The problem of 'bail-outs', especially in liberalising economy has become an important topic for research. New litrature has also examined the factors behind the federal government's motivation for extending or avoiding fiscal 'bail-outs' to fiscally imprudent sub-national governments. There can be a broad range of potential motives for fiscal 'bailouts'. Especially where sub-national government are politically powerful in case of coalition rule at national lavel, it would be difficult federal governments to deny 'bailouts'. The federal government often assumes sub-national debts or make loans to subnational governments to avert fiscal crises. In certain instances, as Brazilian experience shows federal government's policy of 'bail-outs' makes the resources of the central bank available to sub-national governments. Wibbels has examined how federation maintains a 'hard-budget constraints' for sub-national governments. He studies how representation of states in the parliament/congress and constitutional rule governing national financial decisions affect the likelihood of bail-outs. For example, if upper house gives equal representation to the states and if there is the bias in representation in favour of poor states then federal government has difficlty in refusing bail-outs. It can be further added here that weak federal government in the case of coalition rules at national level and electoral consideration of ruling coalition can also explain the problem of 'bail-outs'. Problems of 'bail-outs', especially in liberalising economy has become an important topic for further research. Second generation literature attempts to address how the political and fiscal system might be restructured to get out of this dilemma (Wibbels 2004).

Further, second generation scholars have argued that centralisation of tax gives rise to the problems of lage VFI at sub-national levels leading to the large transfers requirement from federal government. The large transfers in turn create problems of accountability at sub-national levels. Transfers, especially discretionary ones are held hostage by vested regional interests and they thus fail to reduce regional economic disparity. Transfers often become a mechanism to bail fiscally irresponsible sub-national governments out of trouble.

Scholars have emphasised that the perverse fiscal behavior is essentially built into the political system. The system itself induces fiscally irresponsible behavior: it is endogenous to the system. The solution to the problem thus involves a fundamental reform 
of political and fiscal institutions to alter the whole structure of incentives for budgetary decision-making.

As noted before the theory of market-preserving federalism failed to elucidate properly how to create 'hard-budget constraints'. Rodden, Eskeland, and Litvack have done case studies of 'soft-budget constraints' encompassing developed countries, developing nations, and transitional economies and have provided further insights. They have observed that 'hierarchical mechanisms' to create 'hard-budget constraints' at subnational level have failed in developing countries. They suggest that 'market-based discipline' is approprate for creating 'hard-budget constraints' for sub-national governments. In other words, a well-developed market economy can itself contribute to 'hard budget constraints'. If sub-national governments with a poor credit rating manages to access to the market for loan, they will either be refused or will have to pay higher interest rates. Second-generation scholars, however, contend that a well-developed credit market system does not exist in developing and transitional countries. In such cases, constitutional rule, for the purpose of imposing balanced-budget constraints at sub-national levels and makeing it unlawful for sub-national governments to over-borrow and run fiscal deficits, can help in creating 'hard-budget constraints' at the sub-national level (Rodden, Eskeland and Litvack 2003).

The second generation litrature also emphasises the decentralisation of tax responsibility. The second generation scholars favour an effective sub-national system of taxation to provide the revenues needed to finance sub-national programmes. The purpose is make sub-national governments responsible for what revenue they raise and what they spend. Decentralisation of revenue responsibilites will lead to less VFI, reducing thereby sub-national dependency on federal transfers. The second-generation scholars argue that the system of inter-governmental transfers must function so as to meet its basic allocative and redistributive functions without being subject to manipulation so as to provide fiscal bail-outs. The SGT is against discretionary transfers which are often used for bailing fiscally imprudent sub-national governments out or electoral gains (Rodden 2002). To put in simple words, inter-governmental system should not create perverse incentives for the federal and sub-national governments. 
It is worth noting that perticuler policy measures that are best suited to a particular country surely depend upon on the specific political, economic, and cultural institutions and its historical traditions. There is no simple, universal blueprint here, but there are some useful guidelines. The next section briefly highlights the importance of comparative study in fiscal federalism.

\section{Conclusion}

Many factors account for the growing interests of scholars in fiscal federalism in the recent times. Globalisation and liberalisation have led to world-wide trend towards decentralisation. Decentralisation was followed by several associated problems especially in developing countries leading to a fresh debate whether decentralisation per se is good for developing countries where sub-national institutions could be weak. Development in EU led to questions of how to assign tax and expenditure responsibilities, between central entity and member states and what would be the role of inter-governmental transfers? International institutions such as World Bank, IMF etc. have also played an important role in facilitating the study/research in fiscal federalism. Finally, the perception that traditional theory cannot adequately explain the present-day institutional arrangements led to the growing interests in fiscal federalism in the recent times.

Broadly speaking, fiscal federalism is concerned with the proper assignment of expenditure and tax responsibilities between federal and sub-national level governments, and design of a proper transfer system.

The study has critically discussed the FGT and SGT. It has been argued that the SGT is more in keeping in line with the later-day institutional reality but this does not mean that the FGT has lost it relevance. FGT and SGT approach the problems of fiscal federalism from different perspectives. While the FGT assumes governments as 'benevolent', the SGT contends that if given opportunity, government may involve in 'rent-seeking activities'. The SGT has emphasised on the incentives created by political process. Second generation theorists have studied two different effect of inter-governmental tarnsfers: incentive of federal government to make transfers of funds; and the incentives these funds create for sub-national governments. 
The FGT does not see any problem in giving most of the service delivery functions to sub-national governments, assuming that decentralisation of public goods and services brings efficiency in their provisions. It also strongly recommends that federal government must be provided with more taxing powers than sub-national governments, for federal government does redistributive, stabilisation and other functions, scope of which is national in character.

The SGT posits that jurisdictions which provide services, should also have power to spend. It contends that that centralisation of taxes leads to 'leviathan' governments which hinder competition. The theory of market-preserving federalism is one of the most influential theory towards building a SGT. It, in brief, suggests that federal system differs significantly in terms of assignment of expenditure and revenue responsibilities and only a federal system with a particular kind of assignment is likely to improve political and economic performance. It further suggests that an appropriately structured federalism requires that sub-national governments have real 'policy authority', face a 'common market' and face a 'hard-budget constraints' (McKinnon 1997).

A number of issues raised by scholars of market-preserving federalism have led to further research/studies by second generation reseachers on fiscal federalism. Second generation research/studies on fiscal federalism today encompasse/s a large and varied literature. The first generation literature of fiscal federalism failed to focus on the incentive effects of transfer systems despite the fact that many transfer systems around the world provide political officials with poor incentives to foster local economic prosperity. The ssecond generation literature of fiscal federalism provides several lessons for the design of transfer systems. It emphasises the importance of sub-national governments in revenue generation with an objective of making sub-national governments more responsive to citizens. In the recent times, scholars have come to recognise the critical importance of establishing 'hard-budget constraints' for different levels of government. 'Soft-budget constraints' give poor incentives and lead to a range of financial and economic problems. A large body of work has been produced relating to various fiscal problems such as 'race to the bottom', the problems with 'soft-budget constraints' for sub-national governments, problems emanating from larger VFI, among others. The recent fiscal federalism literature 
emphasises the role of political and institutional factors in creating adverse incentives for sub-national fiscal behavior.

TABLE 1.1: Conceptual Basis of Expenditure Assignment

\begin{tabular}{|c|c|c|c|}
\hline Expenditure Category & $\begin{array}{l}\text { Service } \\
\text { Responsibility }\end{array}$ & $\begin{array}{l}\text { Provision of } \\
\text { Services }\end{array}$ & Comments \\
\hline Defence & $\mathrm{F}$ & $\mathrm{F}$ & $\begin{array}{l}\text { Benefits/costs national in } \\
\text { scope }\end{array}$ \\
\hline Foreign Affairs & $\mathrm{F}$ & $\bar{F}$ & $\begin{array}{l}\text { Benefits/costs national in } \\
\text { scope }\end{array}$ \\
\hline International Trade & $\mathrm{F}$ & $\bar{F}$ & $\begin{array}{l}\text { Benefits/costs national in } \\
\text { scope }\end{array}$ \\
\hline Environment & $\mathrm{F}$ & S,L & $\begin{array}{l}\text { Benefits/costs national in } \\
\text { scope }\end{array}$ \\
\hline Currency, Banking & $\mathrm{F}$ & $\bar{F}$ & $\begin{array}{l}\text { Benefits/costs national in } \\
\text { scope }\end{array}$ \\
\hline Inter-state Commerce & $\mathrm{F}$ & $\mathrm{F}$ & $\begin{array}{l}\text { Benefits/costs national in } \\
\text { scope }\end{array}$ \\
\hline Immigration & $\mathrm{F}$ & $\bar{F}$ & $\begin{array}{l}\text { Benefits/costs national in } \\
\text { scope }\end{array}$ \\
\hline Unemployment Insurance & $\mathrm{F}$ & $\mathrm{F}$ & $\begin{array}{l}\text { Benefits/costs national in } \\
\text { scope }\end{array}$ \\
\hline Airline /Railway & $\mathrm{F}$ & $\mathrm{F}$ & $\begin{array}{l}\text { Benefits/costs national in } \\
\text { scope }\end{array}$ \\
\hline Industry and Agriculture & $\mathrm{F}, \mathrm{S}, \mathrm{L}$ & S,L & $\begin{array}{l}\text { Significant inter-state spill- } \\
\text { overs }\end{array}$ \\
\hline Education & $\mathrm{F}, \mathrm{S}, \mathrm{L}$ & $\mathrm{S}, \mathrm{L}$ & Transfers in kind \\
\hline Health & $\mathrm{F}, \mathrm{S}, \mathrm{L}$ & S,L & Transfers in kind \\
\hline Social Welfare & $\mathrm{F}, \mathrm{S}, \mathrm{L}$ & $\mathrm{S}, \mathrm{L}$ & Transfers in kind \\
\hline Police & $\mathrm{S}, \mathrm{L}$ & $\mathrm{S}, \mathrm{L}$ & Primarily local benefits \\
\hline Highways & $\overline{F, S, L}$ & $\mathrm{~S}, \mathrm{~L}$ & $\begin{array}{l}\text { Some roads with significant } \\
\text { inter-state spill-overs, others } \\
\text { primarily local }\end{array}$ \\
\hline
\end{tabular}


Notes: F - Federal, S - State/Province, L - Municipality/Local

Source: Anwar Shah, New Fiscal Federalism in Brazil, World Bank Discussion Paper No.124 (Washington, D.C., 1991), p. 7.

\section{TABLE1.2: Conceptual Basis of the Assignment of Tax Responsibilities}

\begin{tabular}{|c|c|c|c|c|}
\hline Tax & $\begin{array}{l}\text { Determination of } \\
\text { Base }\end{array}$ & $\begin{array}{l}\text { Determination of } \\
\text { Rate }\end{array}$ & $\begin{array}{l}\text { Tax Collection } \\
\text { and Admn. }\end{array}$ & Comments \\
\hline Customs & $\bar{F}$ & $\bar{F}$ & $\bar{F}$ & International trade \\
\hline $\begin{array}{l}\text { Income } \\
\text { Tax }\end{array}$ & $\mathrm{F}$ & $\mathrm{F}, \mathrm{S}$ & $\mathrm{F}$ & $\begin{array}{l}\text { Redistributive, mobile } \\
\text { factor }\end{array}$ \\
\hline $\begin{array}{l}\text { Estates and } \\
\text { Gifts }\end{array}$ & $\mathrm{F}$ & $\mathrm{F}, \mathrm{S}$ & $\mathrm{F}$ & Redistributive \\
\hline $\begin{array}{l}\text { Corporate } \\
\text { Tax }\end{array}$ & $\mathrm{F}$ & F,S & $\mathrm{F}$ & Mobile factor \\
\hline $\begin{array}{l}\text { Resource } \\
\text { Tax }\end{array}$ & $\mathrm{F}$ & F,S & $\mathrm{F}$ & Unequally distributed \\
\hline \multirow{2}{*}{$\begin{array}{l}\text { Retails } \\
\text { sails }\end{array}$} & $\mathrm{F}$ & $S$ & $S$ & Higher compliance cost \\
\hline & $\mathrm{F}$ & $\mathrm{S}$ & $\mathrm{F}$ & $\begin{array}{ll}\text { Harmonised, lower } \\
\text { compliance cost }\end{array}$ \\
\hline $\begin{array}{l}\text { Value } \\
\text { Added Tax }\end{array}$ & $\mathrm{F}$ & $\mathrm{F}, \mathrm{S}$ & $\mathrm{F}, \mathrm{SC}$ & $\begin{array}{l}\text { Boarder tax adjustment } \\
\text { possible }\end{array}$ \\
\hline Excise & $S$ & $\mathrm{~S}$ & S & Residence-based taxes \\
\hline $\begin{array}{l}\text { Property } \\
\text { Tax }\end{array}$ & $S$ & $\mathrm{~L}$ & $\mathrm{~L}$ & $\begin{array}{l}\text { Completely immobile } \\
\text { factor, benefit tax }\end{array}$ \\
\hline $\begin{array}{l}\text { User } \\
\text { charges }\end{array}$ & $\mathrm{F}, \mathrm{S}, \mathrm{L}$ & $\mathrm{F}, \mathrm{S}, \mathrm{L}$ & $\mathrm{F}, \mathrm{S}, \mathrm{L}$ & $\begin{array}{lll}\text { Payment for } & \text { service } \\
\text { received } & & \end{array}$ \\
\hline
\end{tabular}

Notes: F - Federal, S - State/Province, L - Municipality/Local, SC - The Council of States

Source: Anwar Shah, New Fiscal Federalism in Brazil, World Bank Discussion Paper No. 124 (Washington, D.C., 1991), p. 11. 


\footnotetext{
'John Maynard Keynes' work (1964) also known as 'Keynesian economics' systemised the technique of smoothing economic cycles through fiscal interventions, and mapped government fiscal tools such as aggregate amounts of government spending, deficit, debt, and taxation. Each of these tools helps control money supply, allowing government to influence the number of people productively employed, the value of money, and the speed at which the economy expands or contracts.

${ }^{2}$ Public choice theorists and neo-institutionalists led by Nobel laureate James Buchannan

${ }^{3}$ International agencies such as World Bank, IMF, IADB and OECD have published massive literature on fiscal federalism and decentralisation.

${ }^{4}$ Musgrave (1959, 132-33, 179-83) offers the classic assignment of powers and responsibilities in a federal structure from the perspective of what level of government is best suited to handle the various task of government. He considers government as benevolent. See also Musgrave and Musgrave (1984, 513-39).

${ }^{5}$ It was Tiebout $(1956,416)$ who developed the decentralisation theorem, which is also known as 'Tiebout Hypothesis'. According to Tiebout, "his model yields a solution for local goods which reflects the preferences of the population more adequately than they can be reflected at national level." Later on, 'Tiebout Hypothesis' was further developed by Oates (1972).

${ }^{6}$ Normative literature assume in principle that federal government always uses the grant for the general welfare, more realistic approach led by public choice theorists provides contrasting views (Brennan and Buchanan 1980, 185).

${ }^{7}$ According to Bird (2004) "If a 'hard budget constraint' is to be effectively imposed by capital markets, not only must there be a credible no-bailout rule, but there must also be full transparency so that lenders have full information on borrowers, and local residents have both full information on the consequences for them of local borrowing and the ability to influence local decision-makers. To the extent that democracy and markets work together in bringing about responsible fiscal behavior, the process is likely to take time." Giving example of Canada, he has argued that "...the hardest budget constraints may be not those set out in legislation but those forged in the fires of experience."

${ }^{8}$ A number of countries have enacted Fiscal Responsibility Law; and recently in India too, states have been provided with some kind of incentives by the union government to enact fiscal responsibility legislation.

${ }^{9}$ Quian and Weingast $(1997,84)$ call the new theory as 'second-generation economic theory' of fiscal federalism.

${ }^{10}$ Barry R. Weingast (1995, 1-31) goes on to argue in historical terms that the eighteenth century England and the US in nineteenth century were systems of market-preserving federalism. He gives credit to their systems of market-preserving federalism for industrial revolution in England and thriving market economy in the US throughout the nineteenth century.

${ }^{11}$ Breton (2000, 15-16) notes: "The benefits and costs that literature ascribes to federalism are really benefits and costs of decentralization and are, therefore, also present in unitary states all of which are, as a matter of observable fact, decentralized. The benefits and costs that are specific to federalism pertain to ownership right regarding constitutional powers".
}

\section{References:}

Ahmad, Ehtisham and Jon Craig (1997), "Intergovernmental Transfers" in Teresa TerMinassian, ed. Fiscal Federalism in Theory and Practice. Washington, D.C.: The World Bank.

Bird, Richard M. (2004), Fiscal Federalism in Russia: A Canadian Perspective, ITP Paper No. 0409, Joseph L. Rotman School of Management, University of Toronto, Toronto. 
Bird, Richard M. and Michael Smart (2002), "Intergovernmental Fiscal Transfers: International Lessons for Developing Countries", World Development, Vol. 30, No. 6, pp. 899-912.

Breton, Albert, "Federalism and Decentralization (2000)", Publius: The Journal of Federalism, Vol. 30, No. 2, pp. 1-46.

Brennan, Geoffrey and James Buchanan (1980), Power to Tax: Analytical Foundation of a Fiscal Constitution. New York: Cambridge University Press.

Buchanan, James M. (1995), "Federalism as an Ideal Political Order and an Objective for Constitutional Reform", Publius: The Journal of Federalism, Vol. 25, No. 2, pp. 19-27.

Inman, Robert P. and Daniel L. Rubinfeld (1997), "Rethinking Federalism", Journal of Economic Perspectives, Vol. 11, No. 4, pp. 43-64.

Jin, Hehui, Yingyi Qian and Barry R. Weingast (2005), "Regional Decentralization and Fiscal Incentives: Federalism, Chinese Style", Journal of Public Economics, Vol. 89, pp. 1719-42.

Joumard, Isabelle and Per Mathis Kongsrud (2003), Fiscal Relations Across Government Levels, Organisation for Economic Co-operation and Development, Economics Department Working Paper, No. 375,

McKinnon, Ronald I. (1997), “The Logic of Market-Preserving Federalism”, Virginia Law Review, Vol. 83, No. 7, pp. 1573-80.

Musgrave, Richard (1959), Theory of Public Finance: A Study in Public Economy. New York: McGraw-Hill.

Musgrave, Richard A. and Peggy B. Musgrave (1984), Public Finance in Theory and Practice. San Francisco: McGraw-Hill.

Oates, Wallace E. (1999), "An Essay on Fiscal Federalism", Journal of Economic Literature, Vol. 37, No.3, pp. 1120-49.

Oates, Wallace E. (2005), "Towards a Second Generation Theory of Fiscal Federalism", International Tax and Public Finance, Vol. 12, No. 4, pp. 349-73.

Oates, Wallace E. (1972), Fiscal Federalism. New York, N.Y.: Harcourt Brace Jovanovich Inc.

Qian, Yingyi and Barry R. Weingast (1997), "Federalism as Commitment to Preserving Market Incentives", Journal of Economic Perspective, Vol. 11, No. 4, pp. 83-92.

Rao, Govinda M. and Nirvikar Singh (2005), Political Economy of Federalism in India. New Delhi: Oxford University.

Rodden, Jonathan (2002), "The Dilemma of Fiscal Federalism: Grants and Fiscal Performance around the World", American Journal of Political Science, Vol. 46, No. 3, pp. 670-87.

Rodden, Jonathan, Gunnar S. Eskeland and Jennie Litvack (2003), "Introduction and Overview" in Jonathan Rodden, Gunnar S. Eskeland and Jennie Litvack, eds., 
Fiscal Decentralization and Challenges of Hard Budget Constraints. Cambridge, Mass., Massachusetts Institute of Technology, pp.1-31.

Rodden, Jonathan and Susan Rose-Ackerman (1997), "Does Federalism Preserve Market?", Vol. 83, No. 7, pp. 1521-72.

Rubinfeld, Daniel L. (1997), “On Federalism and Economic Development”, Virginia Law Review, vol. 83, n. 7, pp. 1581-92.

Shah, Anwar (1991), New Fiscal Federalism in Brazil. Discussion Paper No. 124, Washington, DC: World Bank.

Tanzi, Vito (1995): "Fiscal Federalism and Decentralization: A Review of Some Efficiency and Macroeconomic Aspects", in Michael Bruno and Boris Pleskovic, eds., Annual World Bank Conference on Development Economics (Washington, D.C.: The World Bank)

Watts, Ronald L.(1999), Comparing Federal Systems. Sec. edn., Montreal and Kingston: McGill-Queen's University Press.

Weingast, Barry R. (1995), “The Economic Role of Political Institutions: MarketPreserving Federalism and Economic Development", Journal of Law, Economic \& Organization, Vol. 11, No. 1, pp. 1-31.

Weingast, Barry (2005), "The Performance and Stability of Federalism: An Institutional Perspective', in Menard Claude and Mary M. Shirly, eds., Handbook of New Institutional Economics (Dordrecht, Netherlands), pp. 139-71.

Wibbels, Erik (2003) "Bailouts, Budget Constraints and Leviathan: Comparative Federalism and Lessons from the Early United States", Comparative Political Studies, Vol. 36, No. 5, pp. 475-508.

Wibbels, Erik (2000), "Federalism and the Politics of Macroeconomic Policy and Performance", American Journal of Political Science, Vol. 44, No. 4, pp. 687-702 